\title{
A redescription of Damarchus cavernicola Abraham, 1924, with notes on Damarchus Thorell, 1891 and Atmetocbilus Simon, 1887 (Aranei: Nemesiidae)
}

\section{Переописание Damarcbus cavernicola Abraham, 1924, с замечаниями по видам Damarcbus Thorell, 1891 и Atmetochilus Simon, 1887 (Aranei: Nemesiidae)}

\author{
Sergei L. Zonstein ${ }^{1}$, Yuri M. Marusik ${ }^{2,3}$ \\ С.А. Зонштейн ${ }^{1}$, Ю.М. Марусик ${ }^{2,3}$

\footnotetext{
${ }^{1}$ Department of Zoology, The George S. Wise Faculty of Life Sciences, Tel-Aviv University, 69978 Tel-Aviv, Israel. E-mail: znn@post.tau.ac.il

${ }^{2}$ Institute for Biological Problems of the North RAS, Portovaya Str. 18, Magadan 685000, Russia. E-mail: yurmar@mail.ru

${ }^{2}$ Институт биологических проблем Севера ДВО РАН, Портовая 18, Магадан 685000.

${ }^{3}$ Zoological Museum, University of Turku, FI-20014 Turku, Finland.
}

KEY WORDS: mygalomorph spiders, taxonomy, cave species, Malaysia.

КЛЮЧЕВЫЕ СЛОВА: мигаломорфные пауки, таксономия, пещерные виды, Малайзия.

ABSTRACT. An illustrated redescription of a poorly known nemesiid Damarchus cavernicola Abraham, 1924 = Latouchia batuensis Roewer, 1962, syn.n., found only in Batu Caves, Malaysia is provided. An Indian species Damarchus bifidus Gravely, 1935 is transferred to the related genus Atmetochilus, and a new combination A. bifidus (Gravely, 1935), comb.n. is established.

РЕЗЮМЕ. Дано иллюстрированное переописание малоизвестного немезиида Damarchus cavernicola Abraham, 1924 = Latouchia batuensis Roewer, 1962, syn.n., известного только из пещер Бату (Maлайзия). Индийский вид Damarchus bifidus Gravely, 1935 переводится в близкий род Atmetochilus и устанавливается новая комбинация A. bifidus (Gravely, 1935), comb.n.

\section{Introduction}

Damarchus Thorell, 1891 is one of two known South-Eastern Asian genera of the mygalomorph spider family Nemesiidae (which includes 43 genera and 367 species distributed worldwide mainly in tropical and subtropical zones). The genus encompasses seven species distributed from Eastern India to Singapore and Sumatra [Platnick, 2014]. Although the genus was redefined and rediagnosed by Raven [1985], it remains rather poorly studied: four species are known by one sex; six species are known by only one taxonomic entry and two species have only verbal descriptions. All species were described in 19th and first third of $20^{\text {th }}$ centuries; most of them were not properly illustrated. Only the type species, D. workmanni Thorell, 1891, was the subject of a recent study [Raven, 1985]. Within the genus, the structure of receptacles was shown only for the type species [Raven, 1985: f. 54].

It seems that the real number of species that can be placed in this genus is much higher. Schwendinger [1988] recognized at least six most likely undescribed species in Thailand. While working in SenckenbergMuseum, the senior author found types of Lautochia batuensis Roewer, 1962 (Ctenizidae) from Malaysia. This species was poorly described and illustrated. Although there is a paratype female, it was not illustrated, and male palp and mating spur are incorrectly depicted (Figs 16-17). In addition, we recognized that this species was misplaced in the genus and family. Therefore, we decided to redescribe this species and establish a new combination. Further study revealed that $L$. batuensis is a junior synonym of Damarchus cavernicola Abraham, 1924, a species described from the same caves. Trying to diagnose $D$. cavernicola we recognized that $D$. bifidus Gravely, 1935 is misplaced in the genus. Goals of this paper are as follows: 1) to provide illustrated redescriptions of the types, 2) to transfer two species to the proper family and genera, and 3) to provide synonymy.

\section{Material and methods}

Photographs were taken in dishes of different sizes with paraffin at the bottom. Specimens were photographed using an Olympus Camedia E-520 camera attached to an Olympus SZX16 stereomicroscope at the Zoological Museum, University of Turku. Digital images were prepared using "CombineZP" image stacking software (http://www.hadleyweb.pwp.blueyonder. co.uk/). Illustrations of vulvae were made after macer- 
ation in $20 \%$ potassium hydroxide aqueous solution and exposure for a few minutes in an alcohol/water solution of Chlorazol Black.

All measurements are given in millimeters (for eyes they are also given in parentheses, when include or count tapetum). The abbreviations used in the text are as follows: ALE - anterior lateral eyes; AME anterior median eyes; $\mathrm{d}$ - dorsal; $\mathrm{p}$ - prolateral; PLE - posterior lateral eyes; PLS — posterior lateral spinnerets; PME — median lateral eyes; PMS — posterior median spinnerets; $\mathrm{r}$ - retrolateral; $\mathrm{v}$ - ventral.

\section{Taxonomic survey}

\section{Damarchus Thorell, 1891}

Type species: Damarchus workmanni Thorell, 1891 from Singapore, by monotypy.

\section{Damarchus cavernicola Abraham, 1924} Figs 1-15.

Damarchus cavernicola Abraham, 1924: 1095, Pl. 2, f. 5-7 (†), in Natural History Museum, London, not examined.

Latouchia batuensis Roewer, 1962: 518, f. 1a-c (O'o), in Senckenberg Museum, Frankfurt am Main, examined. Syn.n. MATERIAL. Latouchia batuensis, holotype o' (SMF R-II/ 13909/44; examined), Malaysia, Batu Caves 13 km N Kuala Lumpur, 18.10.1960 (Clark). Paratypes: $1+$, 2 우 subad., 6 juv., same locality, November 1959 - Nov. 1960, same vial, sample number and depository.

NOTE. Vial with holotype contains a label with the name of collector "Clark", but in the text collector indicated as H.E. McClure.

DIAGNOSIS. Damarchus cavernicola can be distinguished from all described congeners by the following characters:

D. montanus (Thorell, 1890) differs from the $D$. cavernicola by the shape of the eye group (AMEs are largest and very closely spaced from each other), female with more densely toothed paired claws on tarsi I-II (5-7 teeth per row); on the contrary, paired tarsal claws of leg IV armed only with 1-2 teeth [ $c f$. Thorell, 1890: 406] vs. 4-5 and 3 in females of D. cavernicola;

D. workmanni Thorell, 1891 differs by the shape of the eye group (by larger and more closely spaced AMEs), and additionally by longer ventroapical process on male tibia I, and by shorter embolus [ $c f$. Thorell, 1891: 15; Figs 17-21];

D. oathesi Thorell, 1895 unlike the D. cavernicola possesses has darker coloration (blackish to brownishblack carapace both in male and female), and more pectinate paired claws (12 teeth vs. 5-6), it also has embolus dilated subapically (tapered in other species) [cf. Thorell, 1895: 3-4];

D. assamensis Hirst, 1909 differs from D. cavernicola by different shape of the mating spur (with longer megaspine), as well as by more thin and less curved embolus (Figs 23-24);

D. excavatus Gravely, 1921 differs from $D$. cavernicola by different shape of the mating spur (with very
Table. Length of leg and palp joints in holotype $\sigma^{7}$ and paratype $q$ (in parentheses) of Latouchia batuensis. Таблица. Length of leg and palp joints in holotype $\sigma^{7}$ and paratype $q$ (in parentheses) of Latouchia batuensis.

\begin{tabular}{|l|c|c|c|c|c|r|}
\hline & Femur & Patella & Tibia & Metatarsus & Tarsus & Total \\
\hline \multirow{2}{*}{ Palp } & 3.30 & 1.65 & 2.78 & & 1.07 & 8.80 \\
& $(3.03)$ & $(1.25)$ & $(2.07)$ & & $(2.13)$ & $(8.48)$ \\
\hline \multirow{2}{*}{ I } & 7.27 & 3.40 & 6.53 & 6.27 & 3.30 & 26.77 \\
& $(4.97)$ & $(2.57)$ & $(3.90)$ & $(3.43)$ & $(2.05)$ & $(17.10)$ \\
\hline \multirow{2}{*}{ II } & 6.47 & 3.07 & 5.77 & 6.20 & 3.15 & 24.66 \\
& $(4.25)$ & $(2.43)$ & $(3.07)$ & $(3.10)$ & $(1.97)$ & $(15.52)$ \\
\hline \multirow{2}{*}{ III } & 5.45 & 2.43 & 4.27 & 6.47 & 2.75 & 21.37 \\
& $(3.27)$ & $(1.90)$ & $(2.17)$ & $(3.03)$ & $(1.67)$ & $(12.04)$ \\
\hline \multirow{2}{*}{ IV } & 7.97 & 2.90 & 6.78 & 9.62 & 3.23 & 30.50 \\
& $(3.05)$ & $(0.83)$ & $(2.57)$ & $(2.18)$ & $(1.30)$ & $(18.73)$ \\
\hline
\end{tabular}

thick single megaspine), and, especially, by metatarsus I provided with basoventral process [Gravely, 1921, f. $7 \mathrm{f}]$.

DESCRIPTION. Male (holotype of Latouchia batuensis). Body length 15.20. Colour in alcohol: carapace intensive light brownish-orange with eye group not darkened; chelicerae brownish-orange; labium, sternum, maxillae, pedipalps and legs almost uniformly light reddish-brown; abdomen with spinnerets light greyish-yellow, dorsal pattern not developed.

General appearance as in Fig. 2. Carapace (Fig. 3) 6.55 long, 1.63 wide. Eye diameters: AME $0.29(0.37)$, ALE 0.38, PLE 0.33, PME 0.27. Interdistances: AMEAME 0.11 (0.06), AME-ALE 0.17 (0.13), ALE-PLE 0.02, PLE-PME 0.03, PME-PME 0.65. Chelicerae without rastellar mound, rastellum composed by $12-15$ thick bristles located in front of fang base. Cheliceral furrow with 8 promarginal teeth and about 25 mesobasal denticles. Labium 0.83 long, 1.13 wide, without cuspules. Maxillae with $c a .80$ small cuspules each (Figs 5-6). Sternum (Fig. 5) 3.42 long, 3.03 wide. Leg measurements as shown in Table.

Spination (femora III-IV with 3-4 dorsal bristles underdeveloped spines; all patellae except III, cymbium and tarsi I-IV aspinose). Pedipalp: femur $\mathrm{d} 0-1-1-$ 1 , p0-0-1; tibia $\mathrm{p} 0-1-1$, v0-0-1. Leg I: femur $\mathrm{d} 0-1-$ $1-1, \mathrm{p} 1-1-1$; tibia $\mathrm{p} 0-1-1, \mathrm{v} 1-2-2+$ megaspine on raised process; metatarsus $\mathrm{p} 1-0-0, \mathrm{v} 1-1-2$. Leg II: femur d1-1-1, p1-1-1; tibia p0-1-1, v1-1-2; metatarsus p1-0-0, v1-1-2. Leg III: femur p1-1-1; tibia $\mathrm{d} 0-1, \mathrm{p} 1-1, \mathrm{r} 1-1, \mathrm{v} 1-2-3$; metatarsus d0-1-1, p1-11, r1-1-1, v1-1-2-2. Leg IV: femur r1-1-1; tibia d0$1-0-0, \mathrm{p} 0-1-0, \mathrm{r} 1-0-0, \mathrm{v} 1-1-2$; metatarsus $\mathrm{d} 0-1-0$, $\mathrm{p} 1-1-1, \mathrm{r} 1-1-1, \mathrm{v} 2-2-1-2$. Mating spur as shown in Fig. 1.

Scopula: distal on metatarsi I-II, entire on tarsi I-II, mixed with short bristles on tarsus III, elsewhere absent. Trichobothria: 2 rows of 7-8 per row on tibiae, 11-13 on metatarsi, 11-12 on tarsi, 8 on cymbium. Paired claws with one S-shaped row of 5-6 teeth. Unpaired claw on tarsi I-IV sharply curved.

Palp as shown in Figs 4, 10-13; femur longer than tibia, tibia wide in the base and thinner in terminal part, embolus as long as bulbus diameter, straight in dorsal view. 


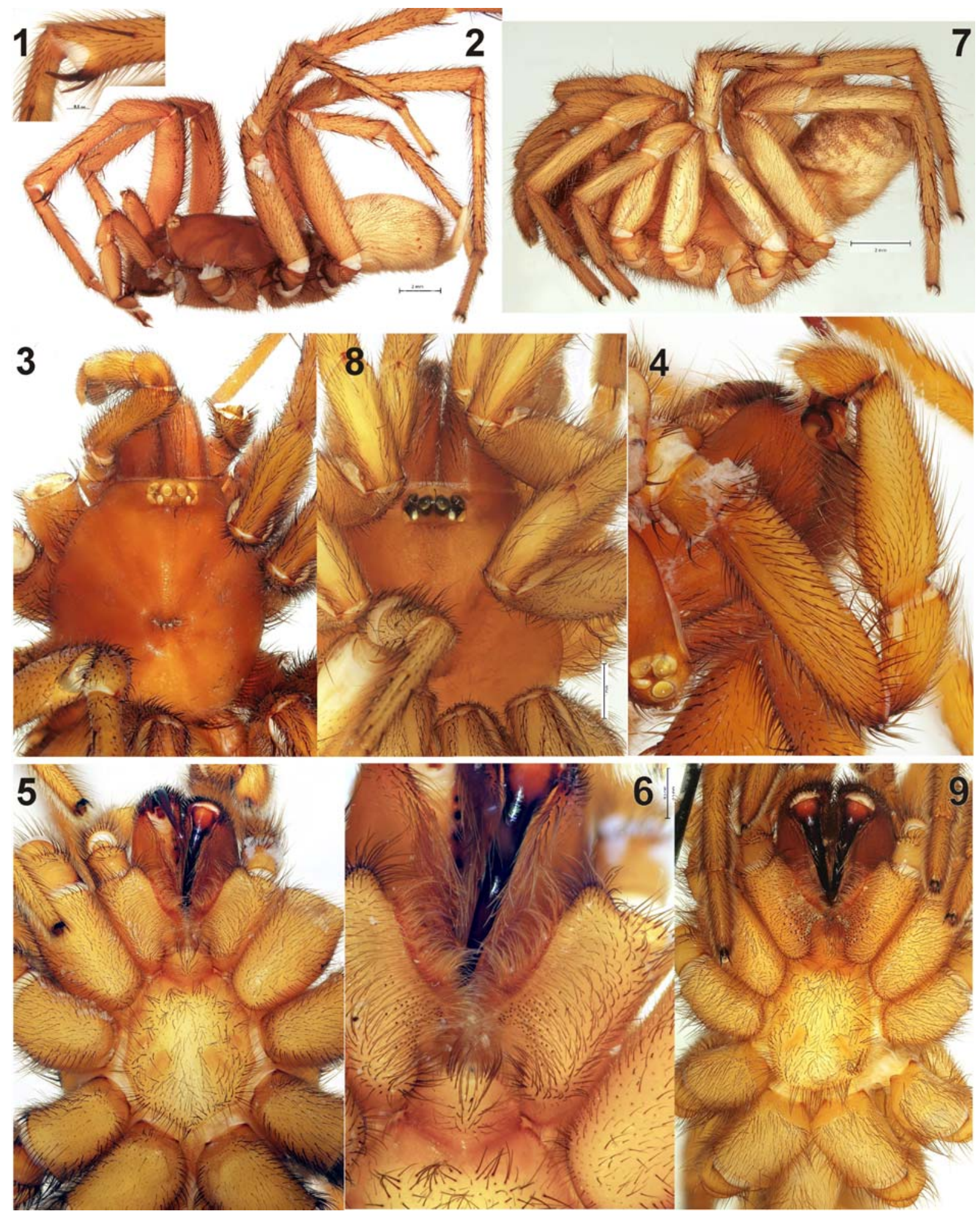

Figs 1-9. Somatic characters of Damarchus cavernicola male (1-6) and female (7-9): 1 - mating spur on tibia I, prolateral; 2,7 habitus, lateral; 3, 8 - prosoma, dorsal; 4 - terminal part of prosoma showing palp, lateral; 5, 9 - prosoma, ventral; 6 - mouth parts, ventral.

Рис. 1-9. Соматические признаки Damarchus cavernicola: самец (1-6) и самка (7-9): 1 - совокупительная шпора на голени I, пролатерально; 2, 7 - габитус, сбоку; 3, 8 - головогрудь, сверху; 4 - передняя часть головогруди с пальпой, сбоку; 5, 9 головогрудь, снизу; 6 - ротовой аппарат, снизу. 

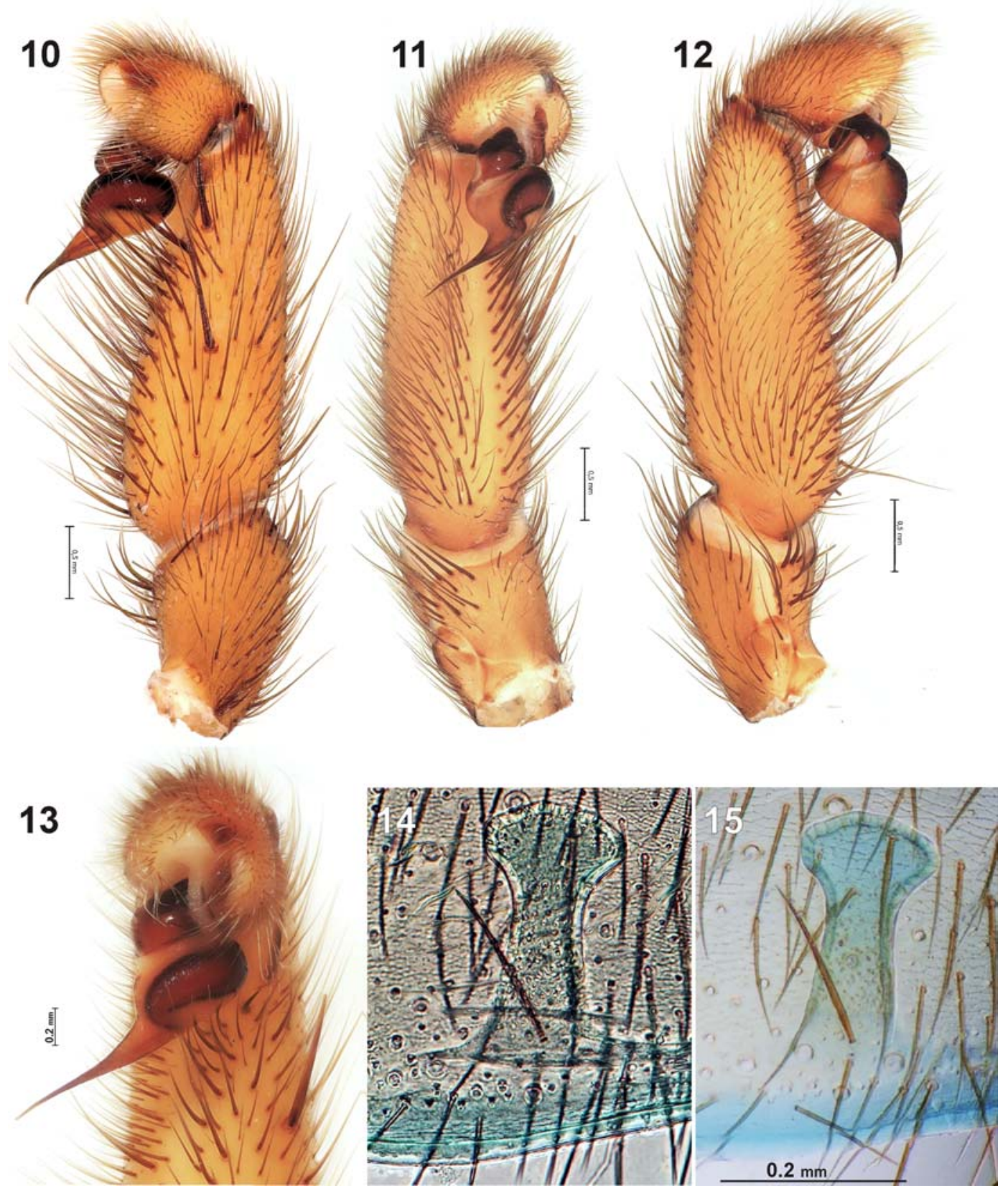

Figs 10-15. Copulatory organs of Damarchus cavernicola: 10-12 - male palp, retrolateral, ventral and prolateral; 13 - male palp, from above; 14-15 - receptacle as it seen in transmitting (14) and reflecting (15) microscopes.

Рис 10-15. Копулятивные органы Damarchus cavernicola: 10-12 - пальпа самца, ретролатерально, снизу и пролатерально; 13 - пальпа самца, сверху; 14-15 - рецептакула снятая на просвечивающем микроскопе (14) и бинокуляре (15).

Female (paratype of Latouchia batuensis): Body length, including chelicerae, 13.2. Colour in alcohol as in male but dorsal abdominal pattern, consisting of numerous irregular light greyish-yellow spots on slightly darker brownish background, better developed.

General appearance as in Fig. 7. Carapace (Fig. 8) 5.63 long, 4.60 wide. Eye diameters: AME 0.21 (0.27), ALE 0.30, PLE 0.22, PME 0.15. Interdistances: AMEAME 0.13 (0.07), AME-ALE 0.12 (0.09), ALE-PLE 0.06, PLE-PME 0.03, PME-PME 0.57. Chelicerae without rastellar mound, rastellum composed by 10-12 thick bristles located in front of fang base. Cheliceral furrow with 8 promarginal teeth and 25-30 mesobasal denticles. Labium 0.70 long, 0.97 wide, with 3 cuspules. Maxillae with ca. 90 cuspules each (Fig. 9). Sternum (Fig. 9) 2.80 long, 2.37 wide. Leg measurements as shown in Table.

Spination (all femora with 3-4 dorsal bristles underdeveloped spines; all patellae except III and tarsi I-IV aspinose). Pedipalp: femur p0-0-1; tibia v1-1-2; 


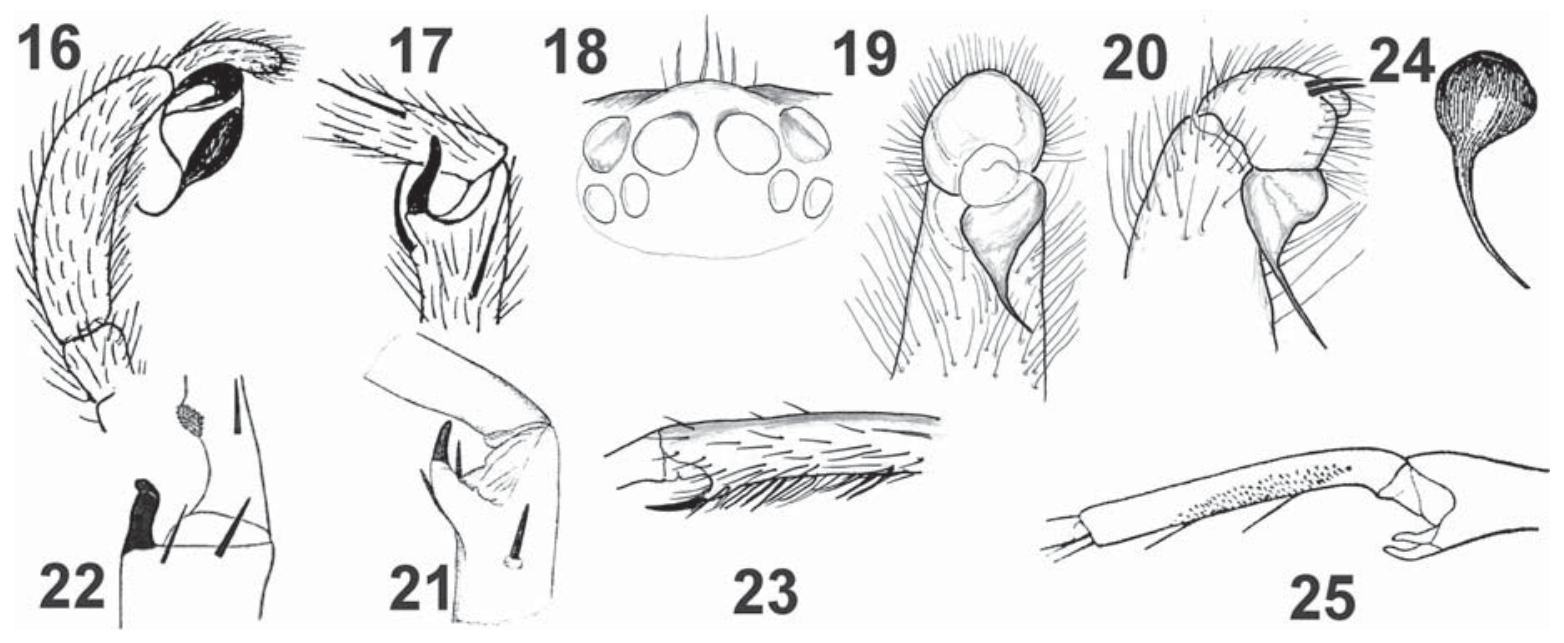

Figs 16-25. Damarchus cavernicola (16-17, after Roewer [1962]), D. workmanni (18-21, after Gravely [1935]), D. excavatus (22, after Gravely [1921]), D. assamensis (23-24, after Hirst [1909]) and Atmetochilus bifidus (25, after Gravely [1935]): 16, 20 — male palp, prolateral; 17, 21-23 - mating spur, prolateral; 18 - male eye tubercle, dorsal; 19 - male palp, ventral; 24 - bulbus, ventral; 25 mating spur and metatarsus, prolateral.

Рис 16-25. Damarchus cavernicola (16-17, по Roewer [1962]), D. workmanni (18-21, по Gravely [1935]), D. excavatus (22, по Gravely [1921]), D. assamensis (23-24, по Hirst [1909]) и Atmetochilus bifidus (25, по Gravely [1935]): 16, 20 — пальпа самца, пролатерально; 17, 21-23 - копулятивная шпора, пролатерально; 18 - глазной бугорок самца, дорзально; 19 - пальпа самца, снизу; 24 - бульбус, снизу; 25 - копулятивная шпора голени и предлапка I, пролатерально.

tarsus v2-0. Leg I: femur p0-0-1; tibia v1-1-1(0); metatarsus v1-1-2. Leg II: p0-0-1; tibia v1-1-0; metatarsus v1-1-2. Leg III: femur p0-0-1, r0-1-1; patella p1-1-2; tibia d1-1, p1-1-1, r1-1, v2-2-3; metatarsus d1-1, p1-1-1, r1-1-1, v2-2-3. Leg IV: femur p0-01 ; r0-0-1; tibia r1-1-1, v2-2-2; metatarsus p1-1-1; r1(0)-1-1, v2(1)-2-1-2.

Scopula: distal on metatarsi I-II, entire on palpal tarsus and tarsi I-II, elsewhere absent. Trichobothria: 2 rows of 8-10 per row on tibiae, 14-16 on metatarsi, 11-12 on tarsi, 8 on palpal tarsus. Paired claws of tarsi I-III with two juxtaposed rows of 4-5 teeth per row; paired claws of tarsi IV with only one outer row composed of 3 teeth. Unpaired claw on tarsi I-IV sharply curved. Palpal claw with 4 promarginal teeth. Receptacles as in Figs 14-15, simple, undivided, fungiform, about 0.3 long; head twice wider than stem.

Spinnerets. PMS: length 0.32; diameter 0.13. PLS: maximum diameter 0.37 ; length of basal, medial and apical segments $0.59,0.37,0.50$; total length 1.46 ; apical segment digitiform.

COMMENTS. Roewer [1962] placed his new species into Latouchia Pocock, 1901, a genus belonging to Ctenizidae. He did not provided any comments or arguments in support of such obviously incorrect placement. Most likely due to wrong placement on the new species, he overlooked a publication by Abraham [1924] in which Damarchus cavernicola was described from the same cave.

While he described an already existing species, Roewer [1962] allocated it correctly, but only on the family level. Both Latouchia and Damarchus Thorell,
1891 were members of the same family, Ctenizidae, until Raven [1985] transferred the latter genus, together with many other "ctenizid" genera, to Nemesiidae.

Nevertheless, it is unclear why the species was assigned to Latouchia, which is diagnosed like other Ctenizinae by modified chelicerae with rastellar mound, legs armed with numerous thorn-like spines, spinose tarsi, one to few teeth arranged in a single row on the paired tarsal claws both in males and females and considerably shortened PLS with domed apical segment. None of these characters can be found in types of $L$. batuensis (see the redescription above). On the contrary, many somatic characters, including the eye arrangement and dentition of the cheliceral furrow in $L$. batuensis wholly correspond to those in $D$. cavernicola [cf. Abraham, 1924, Pl. 2, f. 5, 6a-b]. Hence, we conclude that the Roewer's name should be placed into synonymy of the latter species.

DISTRIBUTION. Known only from the type locality.

\section{Atmetochilus Simon, 1887}

Type species: Atmetochilus fossor Simon, 1887 from Myanmar, by monotypy.

COMMENTS. Until recently only two species have been assigned to this genus: A. atriceps Pocock, 1900 and $A$. fossor. Both species are known by females and from Myanmar only. Only habitus figure was provided for the type species [Simon, 1892, f. 73]. Atmetochilus atriceps was revised and redescribed by Raven [1985]. 
Atmetochilus bifidus (Gravely, 1935), comb.n. Fig. 25.

Damarchus b. Gravely, 1935: 70, f. 1a $\left(0^{7}\right)$.

COMMENTS. We recognized that this species, originally placed in Damarchus, obviously belongs to Atmetochilus thanks to the figure provided by Gravely [1935] and shown in Fig. 25. Although males are not known in Atmetochilus, we are convinced in this placement due to the ongoing revision of this taxon. Undescribed males of this genus have twin spurs and a flattened metatarsus with small spines.

ACKNOWLEDGEMENTS. We thank Peter Jäger and Julia Altmann (Frankfurt am Main) who kindly lent for our study the type series of Latouchia batuensis Roewer, 1962. Special thanks are to Seppo Koponen (University of Turku) for providing museum facilities. Helpful comments on a draft of the manuscript were provided by Mykola M. Kovblyuk (Simferopol), Kadir B. Kunt and Ersen A. Yaðmur (Turkey). The English of the final draft was kindly checked and corrected by Victor Fet (Marshal University, USA). This study was supported in part by the Ministry of Absorption, Israel and the Russian Foundation for Basic Research (grant \# 12-04-01548).

\section{References}

Abraham H.C. 1924. Some mygalomorph spiders from the Malay Peninsula // Proc. Zool. Soc. Lond. Vol.[1924]. P.1091-1124.

Gravely F.H. 1921. The spiders and scorpions of Barkuda Island // Rec. Indian Mus. Calcutta. Vol.22. P.399-421.

Gravely F.H. 1935. Notes on Indian mygalomorph spiders. II. // Rec. Ind. Mus. Calcutta. Vol.37. P.69-84.

Hirst A.S. 1909. On some new or little-known mygalomorph spiders from the Oriental Region and Australasia // Rec. Ind. Mus. Calc. Vol.3. P.383-390.

Raven R.J. 1985. The spider infraorder Mygalomorphae (Araneae): Cladistics and systematics // Bull. Am. Mus. nat. Hist. Vol.182. P. $1-180$.

Roewer C.F. 1962. Einige Arachniden aus den Batu-Caves in Malaya // Pacif. Insects. Vol.4. P.517-520.

Schwendinger P. 1988. Biological observations on orthognathous spiders in northern Thailand (Araneae: Mesothelae, Mygalomorphae) // Haupt J. (ed.). XI. Europäisches Arachnologisches Colloquium. Berlin: TUB-Dokumentationen, Kongresse und Tagungen. Vol.38. P.231-236.

Thorell T. 1890. Studi sui ragni Malesi e Papuani. IV // Ann. Mus. civ. stor. nat. Genova. T.28. P.1-419.

Thorell T. 1891. Spindlar från Nikobarerna och andra delar af södra Asien // Kongl. Svenska. Vet.-Acad. Handl. Vol.24. Nr.2. P.1-149.

Thorell T. 1895. Descriptive catalogue of the spiders of Burma. London. 406 p.

Responsible editor S. Koponen 